Provided for non-commercial research and education use. Not for reproduction, distribution or commercial use.

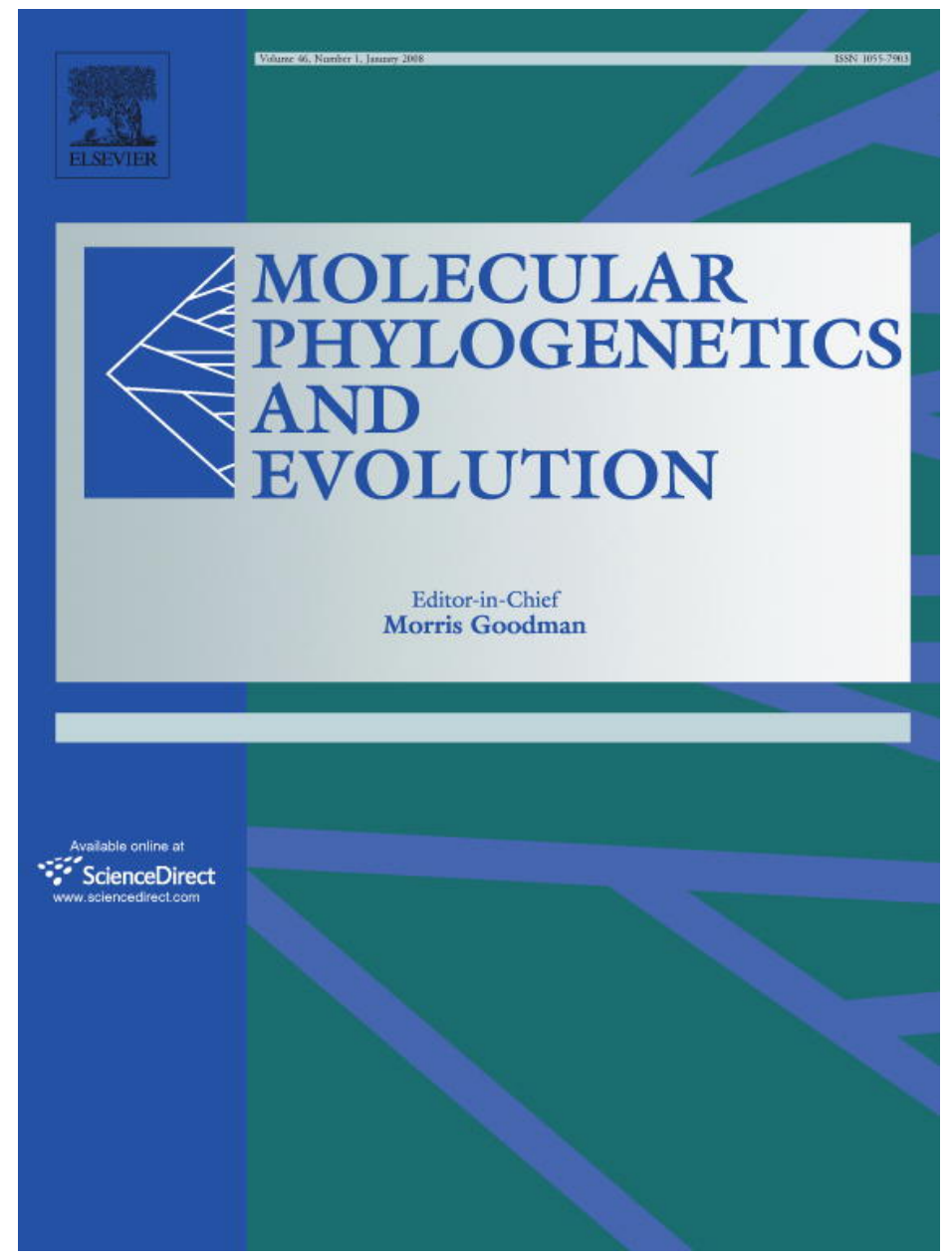

This article was published in an Elsevier journal. The attached copy

is furnished to the author for non-commercial research and education use, including for instruction at the author's institution, sharing with colleagues and providing to institution administration.

Other uses, including reproduction and distribution, or selling or licensing copies, or posting to personal, institutional or third party websites are prohibited.

In most cases authors are permitted to post their version of the article (e.g. in Word or Tex form) to their personal website or institutional repository. Authors requiring further information regarding Elsevier's archiving and manuscript policies are encouraged to visit:

http://www.elsevier.com/copyright 


\title{
Insights on speciation patterns in the genus Iberochondrostoma (Cyprinidae): Evidence from mitochondrial and nuclear data
}

\author{
J.I. Robalo ${ }^{\mathrm{a}, \mathrm{c}, *}$, I. Doadrio $^{\mathrm{b}}$, A. Valente ${ }^{\mathrm{a}, \mathrm{c}}$, V.C. Almada ${ }^{\mathrm{a}}$ \\ ${ }^{a}$ Unidade de Investigação em Eco-Etologia, Instituto Superior de Psicologia Aplicada, Rua Jardim do Tabaco 44, 1149-041 Lisboa, Portugal \\ b Museo Nacional de Ciencias Naturales, José Gutiérrez Abascal 2, 28006 Madrid, Spain \\ ${ }^{\mathrm{c}}$ Departamento de Zoologia e Antropologia, Faculdade de Ciências, Universidade do Porto, Praça Gomes Teixeira, 4099-002 Porto, Portugal
}

Received 31 March 2007; revised 20 June 2007; accepted 10 July 2007

Available online 18 July 2007

\begin{abstract}
In this paper, the patterns of cladogenesis in the cyprinid fish genus Iberochondrostoma were analysed using a mitochondrial (cytochrome $b$ ) and a nuclear (beta-actin) gene fragment. The two genes yielded discordant results. While the cytochrome $b$ gene yielded a fully dichotomous tree, where all species of the genus are monophyletic, the much slower beta-actin gene yielded star-like relationships. However, when information from both genes was considered together, the data suggested the persistence of a very large central unit from which at least two peripheral clades arose at different times. This pattern which is akin to peripatric speciation was shown to be compatible with the paleogeographical information available. It is suggested that combining the techniques of phylogeny and phylogeography and the use of multiple markers varying in their rate of evolution may enrich our understanding of speciation and evolution of clades beyond species level.
\end{abstract}

(c) 2007 Elsevier Inc. All rights reserved.

Keywords: Endemic fish; Cyprinids; Peripatric speciation; SNP analysis; Portugal; Spain

\section{Introduction}

Although much progress has been achieved, a considerable amount of work is still needed to fully bridge the gap between studies of the genetic relationships among populations and those involving taxa beyond the species level.

In phylogeographic studies, emphasis has been placed on the relationships among populations, commonly represented by haplotype networks or star-like tree topologies. These patterns are largely caused by incomplete lineage sorting and absence of reciprocal monophyly (e.g. Avise, 2000). On the contrary, phylogenetic analysis, especially when it is based on the rapidly evolving mitochondrial

\footnotetext{
* Corresponding author. Address: Unidade de Investigação em Eco-Etologia, Instituto Superior de Psicologia Aplicada, Rua Jardim do Tabaco 44, 1149-041 Lisboa, Portugal. Fax: +351 218860954.

E-mail addresses: jrobalo@ispa.pt (J.I. Robalo), mcnd147@ mncn.csic.es (I. Doadrio), acvalent@fc.up.pt (A.Valente), valmada@ ispa.pt (V.C. Almada).
}

genes tends to result in trees presenting dichotomous structures with monophyletic groups. Implicit in many phylogenetic analyses is the assumption that in speciation the ancestral species tend to originate two sister species not very different in size. In this perspective, polytomies are viewed as being usually soft, being due to insufficient sampling, either in the amount of DNA or in the number of taxa. Hard polytomies in turn, would result from a very rapid succession of speciation events which left no record in a given genetic marker (e.g. Page and Holmes, 1998; Poe and Chubb, 2004). Another scenario is however conceivable. Consider a species with a broad geographical distribution and with a large effective population size. Such a "large" species can in different occasions, give rise to new peripheral species with small geographical areas and effective sizes without substantial changes in its genetic structure. Indeed, the larger the effective population size the slower the lineage sorting will be and the split of a small subset like the formation of a new "small" peripheral 
species may be of little consequence for the genetic pool of the large population which gave rise to it. In such situations, "large" species may originate different descendent species at rather separated times.

This speciation pattern can be detected using two or more genetic markers with different rates of evolution and may represent one of the possible explanations for a phenomenon frequently reported in phylogenetic studies: the fact that in many cases, different genes yield different tree topologies (e.g. Russo et al., 1996; Mattern, 2004). The combination of phylogenetic and phylogeographic techniques using large DNA datasets and comprising genes with different rates of evolution may help to recognize the modes of speciation that took place in a clade, namely the hypothesis of peripatric speciation (Mayr, 1982). In this speciation pattern, we expect to find a species with a central position presenting a high level of genetic diversity and ancestral polymorphisms and a few species in its periphery each one with low genetic diversity, small effective population size and geographical area, but revealing much more complete lineage sorting. The same pattern is unlikely to occur if a species gives rise to two species of similar size.

In this paper, we try to test the hypothesis of peripatric speciation using the genus Iberochondrostoma as a model. This genus was recently described (Robalo et al., 2007a) and constitutes an excellent model because it is well characterized from the morphological and molecular point-ofview and has a compact distribution area that occupies the west, centre and south of the Iberian Peninsula, being present almost without exception in all Atlantic basins between Tagus and Guadalquivir. Three of the four species included in this genus are Critically Endangered (Doadrio, 2001; Doadrio and Carmona, 2003a; Cabral et al., 2005; see Fig. 1) thus the study of their genetic structures assumes a great importance for their conservation (Mesquita et al., 2001; Robalo et al., 2007b).

Iberochondrostoma includes the following species at the present moment: I. lemmingii (Steindachner, 1866); I. lusitanicum (Collares-Pereira, 1980); I. oretanum (Doadrio and Carmona, 2003a); I. almacai (Coelho et al., 2005) (for the species distribution see Fig. 1). At least an additional one is awaiting formal description (the populations of I. lusitanicum from the Lower Tagus, adjacent drainages, in this paper collectively named west, and Lagoa de Albufeira, Robalo et al., 2007b). The old reports of I. lemmingii in the Douro drainage have been shown to correspond to a different fish of a distinct genus (Achondrostoma, Robalo et al., 2007a) which is being formally described as a new species.

The hypothesis that the evolution of this genus may have been characterized by the persistence of a large central species which gave rise to several peripheral small daughter species at different times is suggested by the present geographic distribution of the members of the genus (Fig. 1). In addition, it is known that, in the Miocene, many Iberian waters of the area where Iberochondrostoma species live drained to a number of inland lakes, the modern river system being very recent (Plio-Pleistocene) (Friend and Dabrio, 1996; Andeweg, 2002). Thus, the disappearance of the ancient lakes and the association of their remnants to different river systems is compatible with the pattern of speciation outlined above.

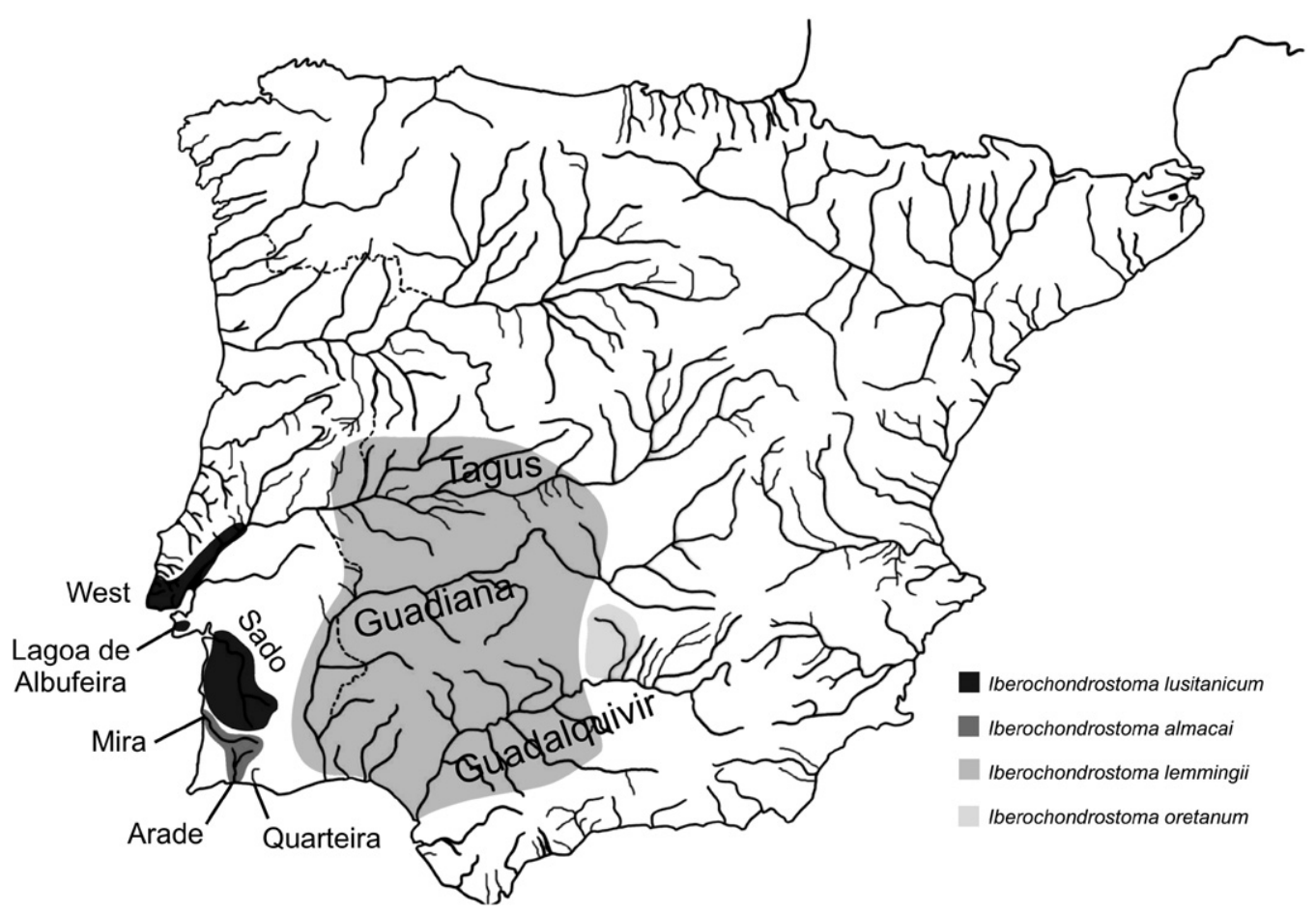

Fig. 1. Map of the Iberian Peninsula with the distribution of the Iberochondrostoma species. 
This paper aims to describe the phylogeography of the entire genus Iberochondrostoma, using two molecular markers, with different rates of evolution. The mitochondrial cytochrome $b$ (cyt $b$ gene) was selected as a rapidly evolving gene, very commonly used in phylogenetic (e.g. Zardoya and Doadrio, 1998, 1999) and phylogeographic studies (Salzburger et al., 2003; Robalo et al., 2006a, 2007b). On the contrary, the nuclear beta-actin gene was selected due to its slow evolution rate (Robalo et al., 2006b, 2007a).

The hypothesis of speciation by peripheral isolation leads to the following predictions: (1) the presence of a central species of large size with several small species surrounding it; (2) more complete lineage sorting in the peripheral species than in the central one, promoted by their smaller sizes; (3) a much higher level of diversity and the persistence of ancestral polymorphisms in the central species.

\section{Methods}

\subsection{Taxon sampling}

The taxa analysed in this study, their collection sites and their corresponding GenBank sequence Accession Nos. are listed in Table 1 (for geographical origin of the samples see Fig. 1). Except in the few cases when not enough biological material was available, the DNA used for PCR and sequencing of both fragments came from the same individual. Voucher specimens are preserved in the fish collections of Museo Nacional de Ciencias Naturales (MNCN) and the Unidade de Investigação em Eco-Etologia, Instituto Superior de Psicologia Aplicada (UIEE/ISPA).

\subsection{DNA analysis}

Total genomic DNA was extracted from fin clips preserved in ethanol by an SDS/proteinase-k based protocol (adapted from Sambrook et al., 1989).

For the cyt $b$ gene, a total of 738 bp was amplified using the primers LCB1-5'-AATGACTTGAAGAACCACC GT-3' (Brito et al., 1997) and HA-5'-CAACGATCTC CGGTTTACAAGAC-3' (Schmidt and Gold, 1993). PCR conditions followed those in Cunha et al. (2004). The amplification process was conducted as follows: 25 cycles of $\left[94{ }^{\circ} \mathrm{C}\right.$ for $1 \mathrm{~min}, 50^{\circ} \mathrm{C}$ for $1 \mathrm{~min}$, and $72{ }^{\circ} \mathrm{C}$ for $2 \mathrm{~min}]$.

For the beta-actin gene, a total of $891 \mathrm{bp}$ was amplified using the primers BactFor-5'-ATGGATGATGAAATTG CCGC- $3^{\prime}$ and BactRev- $5^{\prime}$-AGGATCTTCATGAGGTAG TC-3' (Robalo et al., 2006b). PCR conditions followed those in Robalo et al. (2006b). The amplification process was conducted as follows:

35 cycles of $\left[94{ }^{\circ} \mathrm{C}\right.$ for $30 \mathrm{~s}, 55^{\circ} \mathrm{C}$ for $40 \mathrm{~s}$, and $72{ }^{\circ} \mathrm{C}$ for $1 \mathrm{~min} 30 \mathrm{~s}]$. The amplified fragment is homologous to a region of the beta-actin gene of Cyprinus carpio (GenBank: M24113), including introns B and C and three exons.
Sequencing reactions were performed by Macrogen Inc. in a MJ Research PTC-225 Peltier Thermal Cycler using a ABI PRISM BigDyeTM Terminator Cycle Sequencing Kits with AmpliTaq DNA polymerase (FS enzyme) (Applied Biosystems), following the protocols supplied by the manufacturer.

\subsection{Data analysis}

Sequences were aligned with Clustal X (Thompson et al., 1997). Phylogenetic analyses were performed with PAUP 4.0 (Swofford, 1998) using maximum parsimony (MP) and distance (neighbour-joining, NJ). For the cyt $b$ gene, the molecular evolution model was selected using AIC criterion, as implemented in Modeltest version 3.6. (Posada and Crandall, 1998). For the beta-actin gene, the uncorrected $p$ distance was used instead of selecting a distance with Modeltest because it makes no sense to use a complex model to characterize relationships among very closely related species when using a gene with a very slow mutation rate. For instance, Squalius pyrenaicus and Squalius carolitertii, two sister species that according to cyt $b$ data diverged about 4-6 MYA (Sanjur et al., 2003) did not suffer lineage sorting for beta-actin sharing haplotypes (Robalo et al., 2006b).

Bootstrap analysis was used to assess the relative robustness of branches of the MP (1000 replicates) and the NJ (100 replicates) (Felsenstein, 1985). Whenever for a given gene a haplotype was shared by several fish it was entered only once in the phylogenetic analysis. Achondrostoma oligolepis was used as outgroup in all analyses (GenBank Accession No.: AY254679 for cyt $b$ gene and DQ447713 for beta-actin gene). The following methods were used only in the cyt $b$ dataset due to the low mutation rate of the beta-actin gene. Relationships among haplotypes were analysed with a parsimony network estimated by the software TCS version 1.18 (Clement et al., 2000).

ARLEQUIN software package version 3.01 (Schneider et al., 2000) was used to estimate the genetic diversity in the species studied, to access population differentiation and to perform neutrality tests. Analysis of molecular variance (AMOVA; Excoffier et al., 1992) and pairwise FST were performed whenever sample sizes were adequate. Fu's $F$ s $(\mathrm{Fu}, 1997)$ and Tajima's $D$ (Tajima, 1983) tests were performed to test for possible bottlenecks and population expansion. Mismatch analysis (Rogers and Harpending, 1992; Rogers, 1995) was not attempted because only for the Guadiana did the model fit the data so we felt unjustified to explore them in this direction.

Mean numbers of pairwise differences were corrected by subtracting the average within population differences for the populations of each pair, as implemented in ARLEQUIN. Subsequently, these values were transformed in percent sequence divergence after dividing the number of pairwise differences by the length of the DNA fragment analysed. 
Table

Samples analysed in this study, their collection sites and their corresponding GenBank Accession Nos. for cytochrome $b$ and beta-actin genes

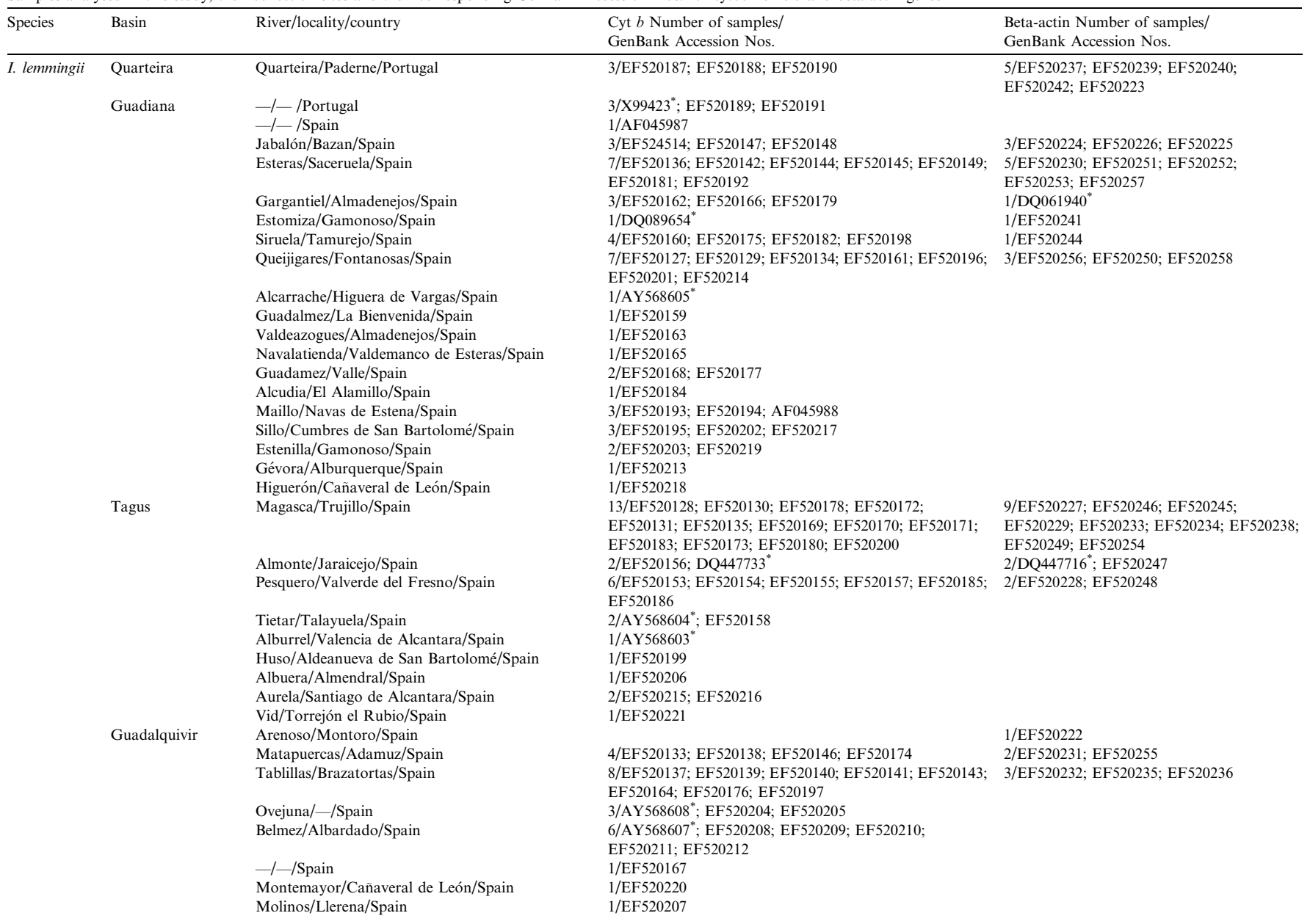



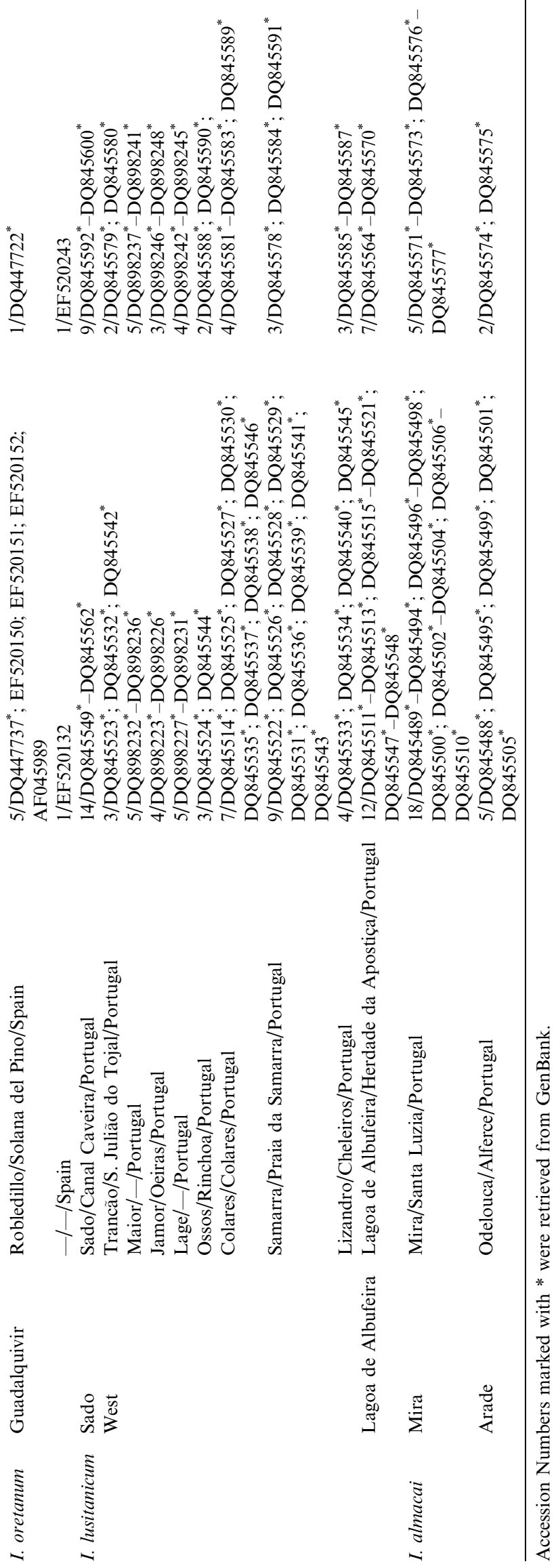

The analysis of the Single Nucleotide Polymorphisms (SNPs) of the beta-actin was made by mapping, in the aligned sequences, all mutations present (fixed or in heterozygozity) in all haplotypes. The synapomorphic states were inferred by comparing the sequences with those of two outgroups: A. oligolepis (GenBank Accession No.: DQ447713; representing the sister clade of Iberochondrostoma, Robalo et al., 2007a) and Protochondrostoma genei (GenBank Accession No.: DQ061938, representing the most ancestral genus of the ones formerly comprised in Chondrostoma, Robalo et al., 2007a,b).

\section{Results}

For the cyt $b$ gene, 167 sites were variable and 10 were parsimony informative. Seventy haplotypes were found in the 197 samples studied. MP analysis resulted in 100 trees retained, with a consensus tree of 249 steps (Consistency index $=0.66$; $\quad$ Homoplasy $\quad$ index $=0.34$; Retention index $=0.92 ;$ CI excluding uninformative characters $=0.55$; HI excluding uninformative characters $=0.45$; Rescaled consistency index $=0.61$ ) (Fig. 2). The MP and NJ trees for cyt $b$ had the same basic topology. The model selected by Modeltest corresponded to GTR $+\mathrm{G}+\mathrm{I}$ with the following assumed nucleotide frequencies: $\mathrm{A}=0.2655$; $\mathrm{C}=0.2673 ; \mathrm{G}=0.1609 ; \mathrm{T}=0.3063$. The assumed proportion of invariable sites was 0.5154 and the distribution of rates at variable sites was equal to the gamma (continuous) distribution with shape parameter $($ alpha $)=1.5260$.

For the beta-actin gene, 16 sites were variable and five were parsimony informative. Twenty-one haplotypes were found in the 86 samples studied. MP analysis resulted in 100 trees retained, with a consensus tree of 23 steps (Consistency index $=0.70$; Homoplasy index $=0.30$; Retention index $=0.46$; CI excluding uninformative characters $=0.42$; HI excluding uninformative characters $=0.58$; Rescaled consistency index $=0.32$ ) (tree not shown).

Only the cyt $b$ tree resulted in a clear dichotomous topology at least at species level (Fig. 2). In this tree, the monophyly of Iberochondrostoma was confirmed with I. almacai in a basal position. Its sister clade splits in two well supported monophyletic groups, one comprising I. lusitanicum from Sado and its geographical neighbour I. lusitanicum from the west and Lagoa de Albufeira, while the other comprises I. lemmingii and I. oretanum. In the populations of I. lemmingii we find, however, some geographical differentiation. All haplotypes (except one) from the Rivers Belmez and Ovejuna (Spain, Guadalquivir basin) are included in a well supported separated clade, suggesting the presence of different haplotypes in the same basin. The remaining haplotypes of I. lemmingii (including those from other Guadalquivir drainages) do not show any relevant geographical association.

For the cyt $b$, dataset AMOVA was performed considering a single group with seven populations: I. lemmingii (Tagus), I. lemmingii (Guadiana), I. lemmingii (Guadalquivir), I. lusitanicum (west), I. lusitanicum (Lagoa de 


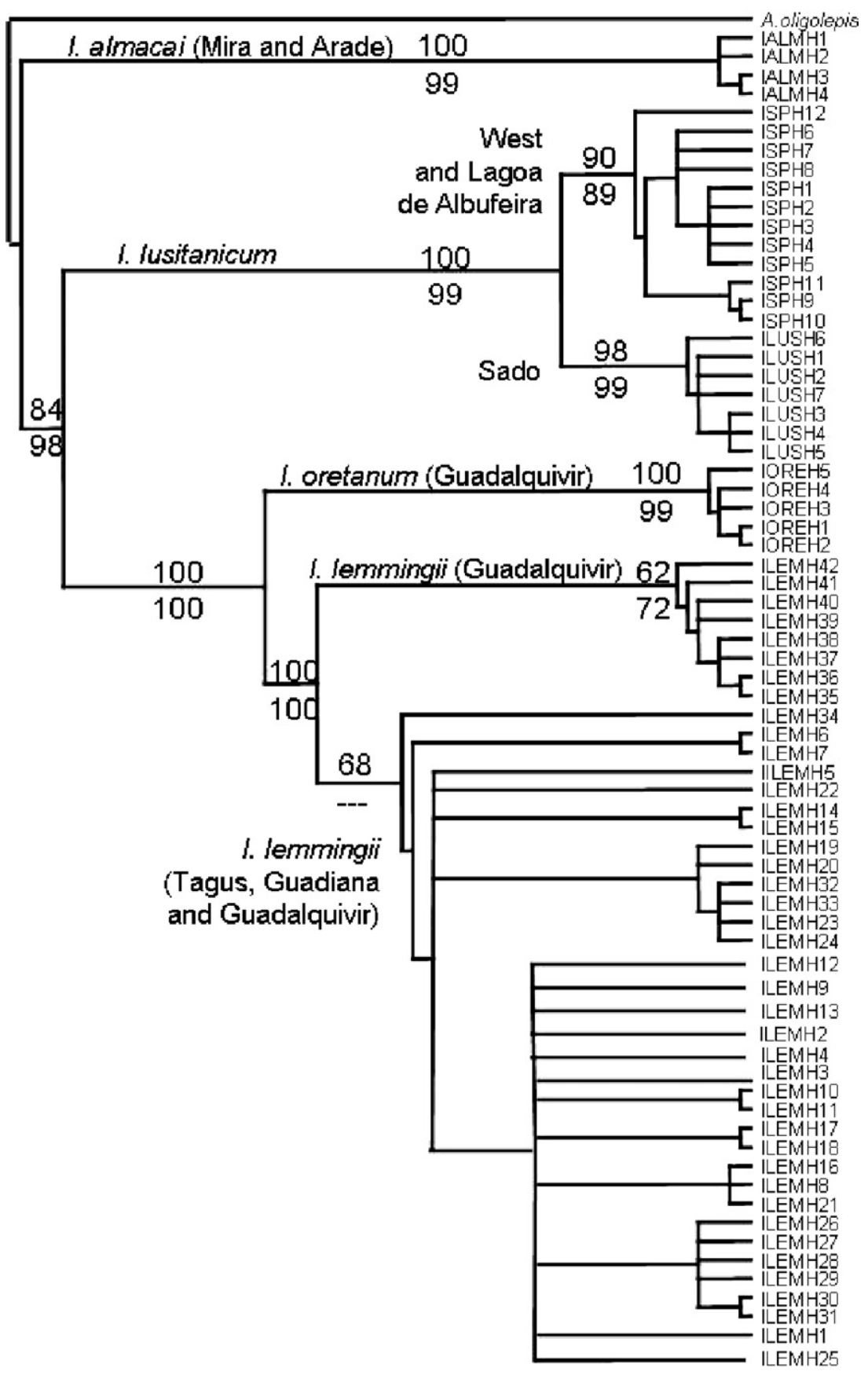

Fig. 2. Tree of cyt $b$ based on MP analysis. Each haplotype was included only once in the tree, regardless of the number of fish that presented it. Numbers above branches represent bootstrap values for MP (1000 replicates) and numbers below branches represent bootstrap values for NJ (100 replicates). Haplotypes are the same considered in TCS (for haplotype labels see the legend of Fig. 3).

Albufeira), I. lusitanicum (Sado), and I. almacai. Populations of I. lemmingii from the Quarteira drainage and from the $I$. oretanum species were not included in this analysis due to their low number of samples. The results showed that among population variation explained $91.87 \%$ of the variance and was highly significant $(p<0.001 ; \mathrm{FST}=$ 0.92). AMOVA was also performed considering three groups, corresponding to the species I. lemmingii, I. lusitanicum, and I. almacai. The results showed that among group variation explained $85.54 \%$ of the variance, among popula- tions within groups $8.45 \%$ and within populations $6.02 \%$ $(p<0.001 ; \mathrm{FSC}=0.58 ; \mathrm{FST}=0.94 ; \mathrm{FCT}=0.86)$.

All comparisons involving pairs of populations were significant at the same $p$ level (Table 2).

Concerning the molecular diversity indices the highest ones are generally found in the southeast in the populations of I. lemmingii from Guadiana and Guadalquivir and in $I$. oretanum. The smallest ones are found in the populations of I. lusitanicum from west and in I. almacai (Table 3). 
Table 2

FSTs for pairs of populations

\begin{tabular}{|c|c|c|c|c|c|c|c|}
\hline & $\begin{array}{l}\text { I. lemmingii } \\
\text { Tagus basin }\end{array}$ & $\begin{array}{l}\text { I. lemmingii } \\
\text { Guadiana basin }\end{array}$ & $\begin{array}{l}\text { I. lemmingii } \\
\text { Guadalquivir } \\
\text { basin }\end{array}$ & $\begin{array}{l}\text { I. lusitanicum } \\
\text { west }\end{array}$ & $\begin{array}{l}\text { I. lusitanicum } \\
\text { Lagoa de } \\
\text { Albufeira }\end{array}$ & $\begin{array}{l}\text { I. lusitanicum } \\
\text { Sado basin }\end{array}$ & I. almacai \\
\hline I. lemmingii Tagus basin & 0.00000 & & & & & & \\
\hline I. lemmingii Guadiana basin & 0.14917 & 0.00000 & & & & & \\
\hline I. lemmingii Guadalquivir basin & 0.22064 & 0.18993 & 0.00000 & & & & \\
\hline I. lusitanicum west & 0.94839 & 0.94796 & 0.91399 & 0.00000 & & & \\
\hline I lusitanicum Lagoa de Albufeira & 0.93104 & 0.93583 & 0.87120 & 0.38752 & 0.00000 & & \\
\hline I. lusitanicum Sado basin & 0.93844 & 0.94118 & 0.88308 & 0.91670 & 0.88812 & 0.00000 & \\
\hline I. almacai & 0.96075 & 0.95998 & 0.92357 & 0.97703 & 0.97537 & 0.98077 & 0.00000 \\
\hline
\end{tabular}

The values of Tajima $D$ and $\mathrm{Fu} F$ s only suggest population growth in the populations of I. lemmingii from Guadiana and I. lusitanicum from Sado (Table 3).

The results of TCS applied to the cyt $b$ haplotypes (using a 95\% confidence interval, Fig. 3) show that each species has its own network. In I. lemmingii the main haplotype, inferred as the ancestral one, is well represented in all basins where the species occurs. The Guadalquivir seems to represent an ancient centre of diversification, with haplotypes similar to the ancestral one but also others very different in the populations of Belmez and Ovejuna. The vast majority of haplotypes from Guadiana are very close to the presumed ancestral one. I. lemmingii haplotypes from Tagus are also in general close to the ancestral, differing in a maximum of six mutations.

The analysis of the beta-actin SNPs (Table 4) showed that heterozygosity is only present in haplotypes of the $I$. lemmingii populations (i.e. all mutations present are fixed in I. lusitanicum, I. almacai, and I. oretanum). Of the 21 mutation sites mapped, seven corresponded to fixed mutations, two to insertions and one to a deletion. Twelve sites were polymorphic and showed some degree of heterozygosity. From these, seven were present in haplotypes representing only one specimen with no geographical meaning and five represented ancestral polymorphisms (i.e. are present in individuals of the different populations of I. lemmingii). Concerning the meaning of the fixed mutations, we can find a derived mutation that gathers all Iberochondrostoma, another that groups I. almacai and haplotypes from the River Jabalón in the upper Guadiana basin, and still another characteristic of $I$. lusitanicum. As referred by Robalo et al. (2007b), the haplotypes of I. lusitanicum from west and Lagoa de Albufeira and I. lusitanicum from Sado differ in two fixed mutations, each being synapomorphic of each of the clades. I. oretanum also has a derived and fixed characteristic mutation, but the same mutation appears in a few $I$. lemmingii from the same basin (Guadalquivir), although only in heterozygosity, a situation that may have resulted from a possible hybridization event or may indicate that the mutation occurred before the separation between I. lemmingii and I. oretanum. Although a fixed mutation was found that groups I. lusitanicum, I. almacai, and the haplotypes from the River Jabalón in the Guadiana basin it is important to point out that the fixed allele shared by these fish corresponded to the primitive state. For the same locus, all the remaining I. lemmingii and I. oretanum shared the same derived allele.

\section{Discussion}

The results obtained with the cyt $b$ gene confirm the monophyly of Iberochondrostoma as well as the monophyly of each species included in this genus.

Concerning the phylogeography of I. lemmingii the first conclusion is that, based on the present results, there is poor geographical differentiation (with many haplotypes shared among drainages) between Tagus, Guadiana, and Guadalquivir, with the exception of the fishes from the Rivers Belmez and Ovejuna from the Guadalquivir basin (Figs. 2 and 3). Their position in relation to the remaining I. lemmingii will need further evaluation because they were not present in the beta-actin dataset due to lack of samples. In I. lemmingii, the Guadalquivir tributaries Belmez and Ovejuna are the only ones to present distinctive haplotypes. All other basins and rivers share several haplotypes and present low corrected pairwise differences among populations, providing at the same time evidence for ancestral polymorphisms and indicating that the events that severed the last connections among these three basins (Tagus, Guadiana, and Guadalquivir) must have been very recent. Assuming a molecular clock of $1 \%$ between lineages per MY (e.g. Dowling et al., 2002; Doadrio and Carmona, 2004; Robalo et al., 2007a) the populations of I. lemmingii of Tagus and Guadiana were connected until about 80,000 years ago.

The basin of the Guadalquivir seems to be a major diversification centre at least at some of its drainages. Apart from the already mentioned populations of the Rivers Belmez and Ovejuna, I. oretanum also had its origin in the Guadalquivir basin.

Taken together, the results derived from cyt $b$ gene show a very broadly distributed species, I. lemmingii, present in the upper part of the Tagus, Guadiana, and Guadalquivir, from which a small albeit genetically diverse I. oretanum, splited about 2 MYA.

The populations of I. lemmingii are clearly more diverse genetically than those of the remaining species of the genus, except perhaps $I$. oretanum. The number of samples of 


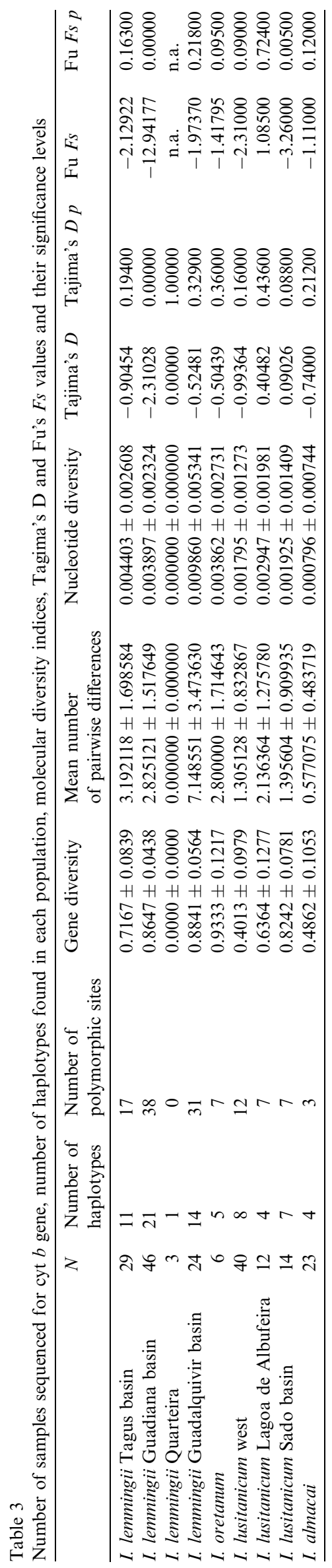

I. oretanum is however too low to draw firm conclusions on this issue. The more peripheral I. almacai and I. lusitanicum from west and Lagoa de Albufeira show the lowest diversity indices.

I. lemmingii retained several ancestral polymorphisms with several haplotypes shared among major basins.

I. almacai and I. lusitanicum correspond to much older splits in Iberochondrostoma. The timing of separation of I. almacai from the remaining fish is about 6/7 MYA and the split of $I$. lusitanicum from I. lemmingii took place about 4, 5/5, 5 MYA. These old phylogroups are all peripheral in geographical location (occurring in the southwest and west of Iberia, respectively), all occupy areas that are much smaller than that of I. lemmingii and present low levels of genetic diversity when compared with those of $I$. lemmingii. This overall pattern is consistent with a scenario of peripatric speciation (Mayr, 1982) with a broadly distributed species located well inside the Iberian Peninsula, originating small peripheral species at different times. Indeed, all three predictions presented in the Section 1 were matched by the results presented above.

This picture is also supported by the analysis of the SNPs in the beta-actin gene. As stated in the Section 3, there is not a single synapomorphic allele specific to I. lemmingii. On the contrary, all the small phylogroups or species (I. lusitanicum, I. almacai, and I. oretanum) have fixed derived alleles, some of which occur in heterozygosity in I. lemmingii. This pattern is the one we would expect if we had a very large population or set of populations with frequent connections in which lineage sorting would proceed slowly and a number of "daughter" peripheral populations in which lineage sorting and allele substitution would proceed much faster (Kimura, 1983). We suggest that the SNP that reflects the oldest split is the one that unites I. almacai and I. lusitanicum. Indeed, it is fixed in all these species and is found in I. lemmingii, although with very low frequency, in the River Jábalon (upper Guadiana). An ancestral polymorphism in the ancient populations that gave rise to what is now I. lemmingii would have become fixed in the colonists that dispersed to the west and southwest of the Iberian Peninsula. This interpretation is consistent with what we know on the geology of Iberia. The present-day river system is very recent, being of Plio-Pleistocene age and took its modern shape and exorheic condition after the peninsula tilted to the west, causing many of its water sheds to drain into the Atlantic. As stated above, in the Miocene, most freshwaters of Iberia drained to several inland lakes. Rivers like Douro, Tagus, and Guadiana did not exist in their present configuration and each of them comprised several drainage systems feeding the inland several lakes (e.g. Andeweg, 2002). For instance, the upper Tagus was connected to the upper Guadiana up to the Pleistocene (Moya-Palomares, 2002) but was separated from the lower Tagus in several occasions during the Mio-Pliocene (Cunha et al., 1993). The lower Tagus, in turn, had a southward extension that approached the south of Portugal in the area that presently corresponds 


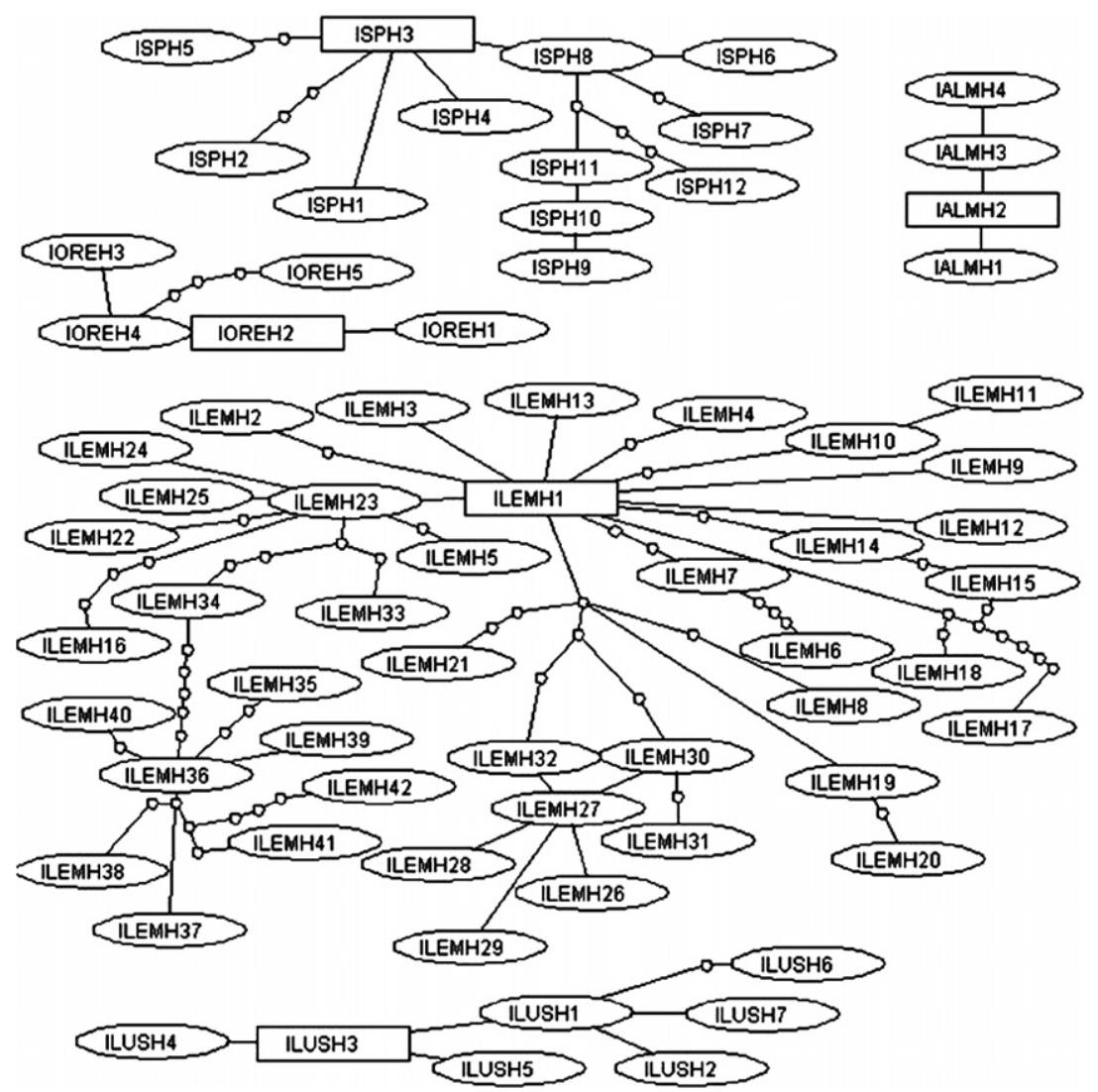

Fig. 3. TCS network. Labels: ILEM $=I$. lemmingii ILUS $=I$. lusitanicum $($ Sado); ISP $=I$. lusitanicum $($ West and Lagoa de Albufeira); IORE $=I$. oretanum; IALM $=$ I. almacai. ILEMH1 $=42$ fish, Tagus, Guadiana, Quarteira, Guadalquivir; ILEMH2 = 1 fish, Guadiana; ILEMH3 = 2 fish, Guadiana; ILEMH4 = 1 fish, Guadiana; ILEM5 = 2 fish, Guadiana; ILEMH6 = 1 fish, Guadiana; ILEMH7 = 1 fish, Guadiana; ILEMH8 = 1 fish, Tagus; ILEMH9 = 1 fish, Guadiana; ILEMH10 = 2 fish, Guadiana; ILEMH11 = 2 fish, Guadalquivir; ILEMH12 = 2 fish, Guadiana; ILEMH13 = 1 fish, Guadiana; ILEMH14 = 1 fish, Guadiana; ILEMH15 = 1 fish, Tagus; ILEMH16 = 1 fish, Guadiana; ILEMH17 = 1 fish, Guadiana; ILEMH18 = 1 fish, Guadiana; ILEMH19=2 fish, Guadiana; ILEMH20 = 1 fish, Guadalquivir; ILEMH21 = 1 fish, Guadalquivir; ILEMH22=1 fish, Guadiana; ILEMH23 = 9 fish, Guadiana, Guadalquivir; ILEMH24 = 1 fish, Guadiana; ILEMH25 = 1 fish, Guadiana; ILEMH26=2 fish, Guadiana, Tagus; ILEMH27 = 1 fish, Tagus; ILEMH28 = 1 fish, Tagus; ILEMH29 = 1 fish, Tagus; ILEMH30 = 5 fish, Tagus; ILEMH31 = 1 fish, Tagus; ILEMH32 = 1 fish, Guadiana; ILEMH33 = 1 fish, Tagus; ILEMH34 = 1 fish, Guadalquivir; ILEMH35 = 1 fish, Guadalquivir; ILEMH36 = 1 fish, Guadalquivir; ILEMH37 = 1 fish, Guadalquivir; ILEMH38 = 1 fish, Guadalquivir; ILEMH39= 1 fish, Guadalquivir; ILEMH40 = 1 fish, Guadalquivir; ILEMH41 = 1 fish, Guadalquivir; ILEMH42 = 1 fish, Guadalquivir; IOREH1 = 2 fish, Guadalquivir; IOREH2 = 1 fish, Guadalquivir; IOREH3 = 1 fish, Guadalquivir; IOREH4 = 1 fish, Guadalquivir; IOREH5 = 1 fish, Guadalquivir; ISPH1 = 1 fish, Tagus and adjacent drainages; ISPH2 = 1 fish, Tagus and adjacent drainages; ISPH3 = 31 fish, Tagus and adjacent drainages, Lagoa de Albufeira; ISPH4 $=1$ fish, Tagus and adjacent drainages; ISPH5 $=1$ fish, Tagus and adjacent drainages; ISPH6 = 1 fish, Lagoa de Albufeira; ISPH7 = 1 fish, Lagoa de Albufeira; ISPH8 = 7 fish, Lagoa de Albufeira; ISPH9 = 2 fish, Tagus; ISPH10 = 2 fish, Tagus; ISPH11 = 1 fish, Tagus; ISPH12 = 3 fish, Lagoa de Albufeira; ILUSH1 = 4 fish, Sado; ILUSH2 = 1 fish, Sado; ILUSH3 = 5 fish, Sado; ILUSH4 = 1 fish, Sado; ILUSH5 = 1 fish, Sado; ILUSH6 = 1 fish, Sado; ILUSH7 = 1 fish, Sado; IALMH1 = 1 fish, Arade; IALMH2 = 16 fish, Arade, Mira; IALMH3 = 5 fish, Mira; IALMH4 = 1 fish, Mira.

to the Sado basin (Teresa Azevedo, personal communication). We suggest that in the upper Miocene (judging from the cyt $b$ data) fish from the upper Tagus, upper Guadiana, and belonging to the stock that gave rise to I. lemmingii manage to reach the lower Tagus. From the lower Tagus/ Sado, this ancestral stock would have spread to the southwest of Portugal where it originated I. almacai. It is interesting to note that fossils of Squalius, another cyprinid genus, are known from the Miocene of the lower Tagus (Póvoa de Santarém, Gaudant, 1977) and in Squalius, there are also species with very restricted ranges in the southwest of Portugal (S. torgalensis and S. aradensis; Coelho et al., 1998) implying a connection of the lower Tagus/Sado with the bulk of the Peninsula and a corridor that allowed the dispersal of fish to southwest Portugal. The separation of the Squalius species of southwest Portugal points to a similar timing as the separation of I. almacai (around 6 MYA, Sanjur et al., 2003; Doadrio and Carmona, 2003b). The differentiation of the Tagus and Sado during the Pliocene promoted the speciation of I. lusitanicum from West/Lagoa de Albufeira and I. lusitanicum, respectively. There is ample geological evidence that the lower Tagus and Sado were connected at some periods and both rivers suffered very pronounced marine transgressions (Pimentel, 1997; Andeweg, 2002) that would have pushed their populations of Iberochondrostoma to the respective headwaters, accelerating lineage sorting and genetic differentiation. In the Pliocene, the connection between upper and lower Tagus was 
Table 4

SNPs found and analysed in the beta-actin gene

\begin{tabular}{|c|c|c|c|c|c|c|c|c|c|c|c|c|c|c|c|c|c|c|c|c|c|}
\hline Haplotypes $\backslash b p$ & 73 & 101 & 108 & 114 & 122 & 138 & 204 & 296 & 385 & 424 & 447 & 455 & 482 & 518 & 520 & 528 & 604 & 608 & 611 & 677 & $720-721$ \\
\hline IlembactH1 & A & & A & $\mathrm{C}$ & $\mathrm{T}$ & $\mathrm{C}$ & G & A & $\mathrm{C}$ & G & $\mathrm{T}$ & $\mathrm{C}$ & & $\mathrm{T}$ & $\mathrm{T}$ & $\mathrm{C}$ & $\mathrm{C}$ & A & $\mathrm{C}$ & G & $\mathrm{CT}$ \\
\hline IorebactH1 & A & & A & $\mathrm{C}$ & $\mathrm{T}$ & $\mathrm{C}$ & G & A & $\mathrm{C}$ & G & $\mathrm{T}$ & $\mathrm{C}$ & & A & $\mathrm{T}$ & $\mathrm{C}$ & $\mathrm{C}$ & A & $\mathrm{C}$ & G & $\mathrm{CT}$ \\
\hline IlembactH2 & A & & A & $\mathrm{C}$ & $\mathrm{T}$ & $\mathrm{C}$ & G & A & $\mathrm{C}$ & G & $\mathrm{Y}$ & $\mathrm{C}$ & & $\mathrm{T}$ & $\mathrm{T}$ & $\mathrm{C}$ & $\mathrm{C}$ & A & $\mathrm{C}$ & G & $\mathrm{CT}$ \\
\hline IlembactH3 & A & & A & $\mathrm{C}$ & $\mathrm{T}$ & $\mathrm{C}$ & G & A & $\mathrm{C}$ & G & $\mathrm{Y}$ & $\mathrm{C}$ & & W & $\mathrm{T}$ & $\mathrm{C}$ & $\mathrm{C}$ & A & $\mathrm{C}$ & G & $\mathrm{CT}$ \\
\hline IlembactH4 & A & & A & $\mathrm{C}$ & $\mathrm{T}$ & $\mathrm{C}$ & $\mathrm{R}$ & $\mathrm{R}$ & $\mathrm{C}$ & G & $\mathrm{C}$ & $\mathrm{C}$ & & $\mathrm{T}$ & $\mathrm{T}$ & $\mathrm{Y}$ & $\mathrm{C}$ & A & $\mathrm{Y}$ & G & $\mathrm{CT}$ \\
\hline IlembactH5 & A & & A & $\mathrm{C}$ & $\mathrm{T}$ & $\mathrm{C}$ & G & A & $\mathrm{C}$ & G & $\mathrm{C}$ & $\mathrm{C}$ & & $\mathrm{T}$ & $\mathrm{K}$ & $\mathrm{C}$ & $\mathrm{C}$ & A & $\mathrm{C}$ & G & $\mathrm{CT}$ \\
\hline IlembactH6 & A & & A & $\mathrm{C}$ & $\mathrm{T}$ & $\mathrm{C}$ & G & A & $\mathrm{C}$ & G & $\mathrm{C}$ & $\mathrm{C}$ & & $\mathrm{T}$ & $\mathrm{T}$ & $\mathrm{C}$ & $\mathrm{C}$ & A & $\mathrm{C}$ & G & $\mathrm{CT}$ \\
\hline IspbactH1 & G & & A & $\mathrm{C}$ & G & $\mathrm{C}$ & G & A & $\mathrm{C}$ & G & $\mathrm{C}$ & $\mathrm{C}$ & & $\mathrm{T}$ & $\mathrm{T}$ & $\mathrm{C}$ & A & A & $\mathrm{C}$ & G & CT \\
\hline IlusbactH1 & G & & A & $\mathrm{C}$ & G & $\mathrm{C}$ & G & A & $\mathrm{C}$ & G & $\mathrm{C}$ & $\mathrm{C}$ & & $\mathrm{T}$ & $\mathrm{T}$ & $\mathrm{C}$ & $\mathrm{C}$ & A & $\mathrm{C}$ & G & \\
\hline IlembactH7 & A & $\mathrm{T}$ & A & $\mathrm{C}$ & G & $\mathrm{C}$ & G & A & $\mathrm{C}$ & G & $\mathrm{C}$ & $\mathrm{C}$ & & $\mathrm{T}$ & $\mathrm{T}$ & $\mathrm{C}$ & $\mathrm{C}$ & A & $\mathrm{C}$ & G & $\mathrm{CT}$ \\
\hline IlembactH8 & A & $\mathrm{T}$ & A & $\mathrm{S}$ & G & $\mathrm{C}$ & G & A & $\mathrm{C}$ & G & $\mathrm{C}$ & $\mathrm{C}$ & & $\mathrm{T}$ & $\mathrm{T}$ & $\mathrm{C}$ & $\mathrm{C}$ & A & $\mathrm{C}$ & G & $\mathrm{CT}$ \\
\hline IlembactH9 & A & $\mathrm{T}$ & A & $\mathrm{C}$ & G & $\mathrm{C}$ & G & A & $\mathrm{C}$ & A & $\mathrm{C}$ & $\mathrm{C}$ & & $\mathrm{T}$ & $\mathrm{T}$ & $\mathrm{C}$ & $\mathrm{C}$ & A & $\mathrm{C}$ & G & $\mathrm{CT}$ \\
\hline IalmbactH1 & A & $\mathrm{T}$ & A & $\mathrm{C}$ & G & $\mathrm{C}$ & G & A & $\mathrm{C}$ & G & $\mathrm{T}$ & $\mathrm{T}$ & $\mathrm{T}$ & $\mathrm{T}$ & $\mathrm{T}$ & $\mathrm{C}$ & $\mathrm{C}$ & G & $\mathrm{C}$ & G & $\mathrm{CT}$ \\
\hline IlembactH10 & A & & $\mathrm{T}$ & $\mathrm{C}$ & $\mathrm{T}$ & G & G & A & $\mathrm{C}$ & G & $\mathrm{C}$ & $\mathrm{C}$ & & $\mathrm{T}$ & $\mathrm{T}$ & $\mathrm{C}$ & $\mathrm{C}$ & A & $\mathrm{C}$ & $\mathrm{K}$ & CT \\
\hline IlembactH11 & A & & $\mathrm{T}$ & $\mathrm{C}$ & $\mathrm{T}$ & G & G & A & $\mathrm{C}$ & G & $\mathrm{C}$ & $\mathrm{C}$ & & $\mathrm{T}$ & $\mathrm{T}$ & $\mathrm{C}$ & $\mathrm{C}$ & A & $\mathrm{C}$ & $\mathrm{T}$ & $\mathrm{CT}$ \\
\hline IlembactH12 & A & & $\mathrm{T}$ & $\mathrm{C}$ & $\mathrm{T}$ & G & G & A & $\mathrm{C}$ & G & $\mathrm{C}$ & $\mathrm{C}$ & & $\mathrm{T}$ & $\mathrm{T}$ & $\mathrm{C}$ & $\mathrm{C}$ & A & $\mathrm{C}$ & G & CT \\
\hline IlembactH13 & A & & W & $\mathrm{C}$ & $\mathrm{T}$ & $\mathrm{S}$ & G & A & $\mathrm{C}$ & G & $\mathrm{Y}$ & $\mathrm{C}$ & & W & $\mathrm{T}$ & $\mathrm{C}$ & $\mathrm{C}$ & A & $\mathrm{C}$ & G & $\mathrm{CT}$ \\
\hline IlembactH14 & A & & W & $\mathrm{C}$ & $\mathrm{T}$ & $\mathrm{S}$ & G & A & $\mathrm{Y}$ & G & $\mathrm{Y}$ & $\mathrm{C}$ & & $\mathrm{K}$ & $\mathrm{T}$ & $\mathrm{C}$ & $\mathrm{C}$ & A & $\mathrm{C}$ & G & $\mathrm{CT}$ \\
\hline IlembactH15 & A & & W & $\mathrm{C}$ & $\mathrm{T}$ & $\mathrm{S}$ & G & A & $\mathrm{C}$ & G & $\mathrm{Y}$ & $\mathrm{C}$ & & $\mathrm{T}$ & $\mathrm{T}$ & $\mathrm{C}$ & $\mathrm{C}$ & A & $\mathrm{C}$ & G & $\mathrm{CT}$ \\
\hline IlembactH16 & A & & W & $\mathrm{C}$ & $\mathrm{T}$ & $\mathrm{S}$ & G & A & $\mathrm{C}$ & G & $\mathrm{C}$ & $\mathrm{C}$ & & $\mathrm{T}$ & $\mathrm{T}$ & $\mathrm{C}$ & $\mathrm{C}$ & A & $\mathrm{C}$ & G & CT \\
\hline IlembactH17 & A & & W & $\mathrm{C}$ & $\mathrm{T}$ & $\mathrm{S}$ & G & A & $\mathrm{C}$ & G & $\mathrm{C}$ & $\mathrm{C}$ & & $\mathrm{T}$ & $\mathrm{T}$ & $\mathrm{C}$ & $\mathrm{C}$ & A & $\mathrm{C}$ & $\mathrm{K}$ & CT \\
\hline A. oligolepis & A & & A & $\mathrm{T}$ & G & $\mathrm{C}$ & G & A & $\mathrm{C}$ & G & $\mathrm{C}$ & $\mathrm{C}$ & & $\mathrm{T}$ & $\mathrm{T}$ & $\mathrm{C}$ & $\mathrm{C}$ & A & $\mathrm{C}$ & G & CT \\
\hline P. genei & A & & A & $\mathrm{T}$ & G & $\mathrm{C}$ & G & A & $\mathrm{C}$ & G & $\mathrm{C}$ & $\mathrm{C}$ & & $\mathrm{T}$ & $\mathrm{T}$ & $\mathrm{C}$ & $\mathrm{C}$ & A & $\mathrm{C}$ & G & CT \\
\hline
\end{tabular}

Ilembact $=$ haplotypes for I. lemmingii; Iorebact = haplotypes for I. oretanum; Ispbact = haplotypes for I. lusitanicum (west and Lagoa de Albufeira); Ilusbact $=$ haplotypes for I. lusitanicum (Sado); Ialmbact $=$ haplotypes for $I$. almacai; IlembactH1 = 3 individuals; Tagus, Guadalquivir; IorebactH1 = 1 fish, Guadalquivir; IlembactH2 = 2 fish, Tagus, Guadalquivir; IlembactH3 = 1 fish, Guadalquivir; IlembactH4 = 1 fish, Tagus; IlembactH5 = 1 fish, Tagus; IlembactH6 = 3 fish, Tagus, Guadiana; Ispbact H1 = 40 fish, Tagus and adjacent basins, Lagoa de Albufeira; IlusbactH1 = 9 fish, Sado; IlembactH7 = 1 fish, Guadiana; IlembactH8 = 1 fish, Guadiana; IlembactH9 = 1 fish, Guadiana; IalmbactH1 = 7 fish, Mira, Arade; IlembactH10 = 1 fish, Tagus; IlembactH11 = 1 fish, Guadalquivir; IlembactH12 = 10 fish, Quarteira, Guadiana, Guadalquivir; IlembactH13 = 1 fish, Guadalquivir; IlembactH14 = 1 fish, Guadiana; IlembactH15 = 1 fish, Tagus; IlembactH16 = 8 fish, Tagus, Guadiana; IlembactH17 = 1 fish, Tagus.

severed (Cunha et al., 1993; Andeweg, 2002) avoiding that new waves of I. lemmingii reinvaded the lower reaches of the Tagus. Even nowadays, with the Tagus being a continuous river, I. lemmingii is restricted to the Spanish part of the Tagus and a few tributaries near the Portuguese boarder, while I. lusitanicum from west and Lagoa de Albufeira is restricted to the tributaries closest to the estuary.

Overall, the paleobiogeographical information available is compatible with the scenario of a large species giving rise to two smaller ones at different periods and further fragmentation of one of these smaller entities.

Two notes of caution are needed:

(1) This sequence of events assumes that the few SNPs involved did not suffer recurrent mutations that would cause homoplasy. The low number of polymorphic sites is in our view, consistent with this possibility.

(2) The low genetic diversity of the peripheral species may have also resulted from bottlenecks that occurred after their differentiation, namely strong marine transgressions in the western rivers, causing drastic reductions in population size.

The use of other nuclear markers will help to test the validity of the model presented in this paper.

In conclusion, we note that what seemed to be a well resolved dichotomous tree inferred from cyt $b$ did not cor- respond to the picture obtained with a slowly evolving nuclear gene. The slow rate of evolution of this fragment and its fourfold higher effective population size (Zhang and Hewitt, 2003) apparently allowed the preservation of old signatures, of past events that the rapid lineage sorting, that probably took place in the cyt $b$ gene, did not preserve.

We suggest that phylogeographic reconstruction, in particular using SNPs applied to slowly evolving nuclear genes, in combination with phylogenetic analysis, may help us to get a better understanding of the evolutionary history of clades beyond the species level, an essential step to study speciation.

\section{Acknowledgments}

We thank C. Sousa-Santos, S. Pera, J.A. Carmona, and T. Bento for all the help in sample collection and fish maintenance, respectively, and M. Arruda for the samples of $I$. lusitanicum from the River Maior. We also thank C. SousaSantos for drawing the distribution map presented in this paper. DGRF ("Direcção Geral dos Recursos Florestais") and ICN ("Instituto da Conservação da Natureza") provided all authorizations for field work. This study was funded by the Pluriannual Program (FCT, UI\&D 331/94, partially FEDER funded). 


\section{References}

Andeweg, B., 2002. Cenozoic tectonic evolution of the Iberian Peninsula. Causes and effects of changing stress fields. Ph.D. thesis, Vrije Universiteit, Amsterdam.

Avise, J.C., 2000. Phylogeography. The History and Formation of Species. Harvard University Press, Cambridge.

Brito, R.M., Briolay, J., Galtier, N., Bouvet, Y., Coelho, M.M., 1997. Phylogenetic relationships within genus Leuciscus (Pisces, Cyprinidae) in Portuguese fresh waters, based on mitochondrial cytochrome $b$ sequences. Mol. Phylogenet. Evol. 8, 435-442.

Cabral, M.J., Almeida, J., Almeida, P.R., Dellinger, T., Ferrand de Almeida, N., Oliveira, M.E., Palmeirim, J.M., Queiroz, A.I., Rogado, L., Santos-Reis, M. (Eds.), 2005. Livro Vermelho dos Vertebrados de Portugal. Instituto de Conservação da Natureza, Lisboa.

Clement, M., Posada, D., Crandall, K.A., 2000. TCS: a computer program to estimate gene genealogies. Mol. Ecol. 9, 1657-1659.

Coelho, M.M., Bogutskaya, N.G., Rodrigues, J.A., Collares-Pereira, M.J., 1998. Leuciscus torgalensis and Laradensis, two new cyprinids from Portuguese fresh waters. J. Fish Biol. 52 (5), 937-950.

Coelho, M.M., Mesquita, N., Collares-Pereira, M.J., 2005. Chondrostoma almacai, a new cyprinid species from the southwest of Portugal, Iberian Peninsula. Folia Zool. 54 (1-2), 201-212.

Collares-Pereira, M.J., 1980. Les Chondrostoma à bouche arquée de la Péninsule Ibérique (avec la description de Ch. lusitanicum nov. sp.) (Poissons, Cyprinidae). C.R. Acad. Sc. Paris. D 291, 275-278.

Cunha, P.P., Barbosa, B.P., Pena dos Reis, R., 1993. Synthesis of the Piacenzian onshore record between the Aveiro and Setúbal parallels (Western Portuguese margin). In: Proceedings of the first R.C.A.N.S. Congress, Ciências da Terra, 12, pp. 35-43.

Cunha, C., Coelho, M.M., Carmona, J.A., Doadrio, I., 2004. Phylogeographical insights into the origins of the Squalius alburnoides complex via multiple hybridization events. Mol. Ecol. 13, 2807-2817.

Doadrio, I., 2001. Atlas y libro rojo de los peces continentales de Españ a. Dirección General de la Natureza-Museo Nacional de Ciencias Naturales, Madrid.

Doadrio, I., Carmona, J.A., 2003a. A new species of the genus Chondrostoma Agassiz, 1832 (Actinopterygii, Cyprinidae) from the Iberian Peninsula. Graellsia 59, 29-36.

Doadrio, I., Carmona, J.A., 2003b. Testing freshwater Lago Mare dispersal theory on the phylogeny relationships of Iberian cyprinid genera Chondrostoma and Squalius (Cypriniformes, Cyprinidae). Graellsia 59, 457-473.

Doadrio, I., Carmona, J.A., 2004. Phylogenetic relationships and biogeography of the genus Chondrostoma inferred from mitochondrial DNA sequences. Mol. Phylogenet. Evol. 33, 802-815.

Dowling, T.E., Tibbets, C.A., Minckley, W.L., Smith, G.R., 2002. Evolutionary relationships of the plagopterins (Teleostei: Cyprinidae) from cytochrome $b$ sequences. Copeia 2002, 665-678.

Excoffier, L., Smouse, P.E., Quattro, J.M., 1992. Analysis of molecular variance inferred from metric distances among DNA haplotypes: application to human mitochondrial DNA restriction data. Genetics $131,479-491$

Felsenstein, J., 1985. Confidence limits on phylogenies: an approach using the bootstrap. Evolution 39, 783-791.

Friend, P.F., Dabrio, C.J. (Eds.), 1996. Tertiary Basins of Spain: the Stratigraphic Record of Crustal Kinematics. Cambridge University Press, Cambridge.

Fu, Y.X., 1997. Statistical tests of neutrality of mutations against population growth, hitchhiking and background selection. Genetics $147,915-925$

Gaudant, J., 1977. Contribuitions à la Paléontologie du Miocène moyen continental du Bassin du Tage (II) Observations sur les dents pharyngiennes de poissons cyprinidés-Póvoa de Santarém. Ciências da Terra 3, 129-141.

Kimura, M., 1983. The Neutral Theory of Molecular Evolution. Cambridge University Press, Cambridge.
Mattern, M.Y., 2004. Molecular phylogeny of the Gasterosteidae: the importance of using multiple genes. Mol. Phylogenet. Evol. 30, 366377.

Mayr, E., 1982. Processes of speciation in animals. In: Liss, A.R.I. (Ed.), Mechanisms of Speciation. Alan R. Liss Inc., New York, pp. 1-19.

Mesquita, N., Carvalho, G., Shaw, P., Crespo, E., Coelho, M.M., 2001. River basin-related genetic structuring in an endangered fish species, Chondrostoma lusitanicum, based on mtDNA sequencing and RFLP analysis. Heredity 86, 253-264.

Moya Palomares, M.E., 2002. Evolución sedimentológica y geomorfológica de las Vegas Bajas del Guadiana entre Mérida y Badajoz (España). Tesis Doctoral. Universidade Complutense de Madrid, Madrid.

Page, R.D.M., Holmes, E.C., 1998. Molecular Evolution: A Phylogenetic Approach. Blackwell Publishers, Oxford.

Pimentel, N.L., 1997 O Terciário da Bacia do Sado, sedimentologia e análise tectono-sedimentar. Tese de Doutoramento. Universidade de Lisboa, Lisboa.

Poe, S., Chubb, A.L., 2004. Birds in a bush: five genes indicates explosive evolution of avian orders. Evolution 58, 404-415.

Posada, D., Crandall, K.A., 1998. Modeltest: testing the model of DNA substitution (v. 3.6). Bioinformatics 14, 817-818.

Robalo, J.I., Sousa-Santos, C., Almada, V.C., Doadrio, I., 2006 a. Paleobiogeography of two Iberian endemic cyprinid Wshes (Chondrostoma arcasii - Chondrostoma macrolepidotum) inferred from sequence data. J. Hered. 97, 143-149.

Robalo, J.I., Sousa-Santos, C., Levy, A., Almada, V.C., 2006b. Molecular insights on the taxonomic position of the paternal ancestor of the Squalius alburnoides hybridogenetic complex. Mol. Phylogenet. Evol. 39, 276-281.

Robalo, J., Almada, V., Levy, A., Doadrio, I., 2007a. Re-examination and phylogeny of the genus Chondrostoma based on mitochondrial and nuclear data and the definition of 5 new genera. Mol. Phylogenet. Evol. 42, 362-372.

Robalo, J., Doadrio, I., Valente, A., Almada, V.C., 2007b. Identification of Identification of ESUs in the critically endangered Portuguese minnow Chondrostoma lusitanicum Collares-Pereira 1980, based on a phylogeographical analysis. Conserv. Genet. 8 (5), 1225-1229.

Rogers, A.R., 1995. Genetic evidence for a Pleistocene population explosion. Evolution 49, 608-615.

Rogers, A.R., Harpending, H., 1992. Population growth makes waves in the distribution of pairwise genetic differences. Mol. Biol. Evol. 9, 552569.

Russo, C.A.M., Takezaki, N., Masatoshi, N., 1996. Efficient of different genes and different tree-building methods in recovering a known vertebrate phylogeny. Mol. Biol. Evol. 13, 525-536.

Salzburger, W., Brandstatter, A., Gilles, A., Parson, W., Hempel, M., Sturmbauer, C., Meyer, A., 2003. Phylogeography of the vairone (Leuciscus souffia, Risso 1826) in central Europe. Mol. Ecol. 12, 23712386.

Sambrook, J., Fritsch, E.F., Maniatis, T., 1989. Molecular Cloning: A Laboratory Manual, second ed. Cold Spring Harbor Laboratory Press, Cold Spring Harbor, NY.

Sanjur, O.I., Carmona, J.A., Doadrio, I., 2003. Evolutionary and biogeographical patterns within Iberian populations of the genus Squalius inferred from molecular data. Mol. Phylogenet. Evol. 29, 2030 .

Schmidt, T.R., Gold, J.R., 1993. Complete sequence of the mitochondrial cytochrome $b$ gene in the Cherryffin Shinner, Liturus roseipinnis (Teleostei: Cyprinidae). Copeia 3, 880-883.

Schneider, S., Roessli, D., Excoffier, L., 2000. ARLEQUIN Version 2.000: A Software for Population Genetics Analysis. University of Geneva, Geneva.

Steindachner, F., 1866. Ichthyologischer bericht über eine nach Spanien und Portugal unternommene reise. Sitzungsber. Akad. Wiss. Wien. 54, 261-272. 
Swofford, D.L., 1998. PAUP*_Phylogenetic Analysis Using Parsimony (* and Other Methods) version 4.0. Sinauer Associates, Sunderland, MA.

Tajima, F., 1983. Evolutionary relationship of DNA sequences in finite populations. Genetics 105, 437-460.

Thompson, J.D., Gibson, T.J., Plewniak, F., Jeanmougin, F., Higgins, D.G., 1997. The Clustal X windows interface: flexible strategies for multiple sequence alignment aided by quality analysis tools. Nucleic Acids Res. 24, 4876-4882.
Zardoya, R., Doadrio, I., 1998. Phylogenetic relationships of Iberian cyprinids: systematic and biogeographical implications. Proc. R. Soc. Lond. B 265, 1365-1372.

Zardoya, R., Doadrio, I., 1999. Molecular evidence on the evolutionary and biogeographical patterns of European cyprinids. J. Mol. Evol. 49, 227-237.

Zhang, D-X., Hewitt, G.M., 2003. Nuclear DNA analyses in genetic studies of populations: practice, problems, and prospects. Mol. Ecol. 12, 563-584. 